\title{
The Journal of Environment \& Development
}

http://jed.sagepub.com

\section{Varieties of CDM Governance: Some Reflections Peter Newell}

The Journal of Environment Development 2009; 18; 425

DOI: $10.1177 / 1070496509347089$

The online version of this article can be found at: http://jed.sagepub.com/cgi/content/abstract/18/4/425

\author{
Published by: \\ @SAGE \\ http://www.sagepublications.com
}

Additional services and information for The Journal of Environment \& Development can be found at:

Email Alerts: http://jed.sagepub.com/cgi/alerts

Subscriptions: http://jed.sagepub.com/subscriptions

Reprints: http://www.sagepub.com/journalsReprints.nav

Permissions: http://www.sagepub.com/journalsPermissions.nav

Citations http://jed.sagepub.com/cgi/content/refs/18/4/425 


\section{Varieties of CDM Governance: Some Reflections}

\section{Peter Newell'}

The Journal of Environment \& Development I8(4) 425-435

(C) SAGE Publications 2009 Reprints and permission: http://www. sagepub.com/journalsPermissions.nav DOI: $10.1177 / 107049650347089$ http://jed.sagepub.com

(S)AGE

\begin{abstract}
Absract
This overview discusses a series of themes critical to understanding the governance of clean development that cut across each of the case studies showcased in this special issue. Firstly, the question of who draws the boundaries around what is to be governed, what is not, and by whom, where each of the contributions highlight conflicts over which projects and sectors should be part of the CDM and which actors should be charged with their management. Secondly, how we define and what we mean by governance, where I argue for a broader notion of governance that adequately captures the range of governing functions exercised by the plurality of state and non-state actors in this domain. Thirdly, each of themes relates to the question of power: power to define what is and is not clean and sustainable development; the power that determines which countries are able to steer CDM investments toward sectors aligned with their overall development priorities, and the combinations of public and private power that demonstrate as well as explain the varieties of carbon governance documented in this special issue. My argument is that the observed diversity of carbon governance reflects differences in governance in general in those countries. It is impossible politically, and unhelpful conceptually, to attempt to understand carbon and clean development governance without reference to the broader political-economic context in which it is embedded and which it seeks to transform. But whether it is in the area of energy, waste, or forests, CDM governance is incorporated within and predated by political structures, institutions, conflicts, and interests that shape the amenability of a sector and country to pressures toward convergence, standardization, and universalization.
\end{abstract}

\title{
Keywords
}

governance, clean development, power, CDM

The set of articles contained in this special issue make a valuable contribution to current policy debates about the clean development mechanism (CDM) specifically, and to academic debates about the nature and forms of climate governance more broadly.

\footnotetext{
'University of East Anglia, Norwich, UK
}

\section{Corresponding Author:}

Peter Newell, University of East Anglia, Norwich NR4 7TJ, UK

Email:p.newell@uea.ac.uk 
They do so because they are based on extensive and detailed country-level field work the like of which is often missing in these debates and frequently overlooked amid sweeping generalizations about the pros and cons of the CDM as a tool for the promotion of sustainable development. They are also focused on three countries (Brazil, China, and India) that are the leading hosts of CDM projects (between them accounting for $67 \%$ of total projects and $74 \%$ of all certified emission reductions [CERs] generated) and that are among the developing countries with the most significant emissions profile. China is the largest overall (though not per capita) emitter of $\mathrm{CO}_{2}$, whereas Brazil is the fourth largest emitter of greenhouse gases (GHG) when land-use change and forestry is included. These are, therefore, actors that urgently need to be engaged in efforts to bring down overall global emissions of GHG and whose actions serve as signifiers to the rest of the developing world about the desirability of engagement with carbon markets and the possibility of reducing emissions. In other words, what happens in these countries has global repercussions.

The emphasis on varieties of carbon governance is critically important, for it allows us to understand how similar sets of pressures from the international level are responded to and acted upon so differently at national and subnational level. Pressures toward convergence derive from a range of sources: the CDM executive board in the form of approved methodologies and its accreditation (or not) of designated operational entities (DOEs) who are conferred the authority to assess whether projects have delivered claimed emissions reductions and, therefore, should be issued with CERs or not. Signals also emanate from the climate change negotiations and the Conference of the Parties that ultimately exercises authority over the remit of the CDM and is the body to whom the executive board has to report. As sponsors of projects and key actors in carbon markets, the World Bank and other donors create markets and, through capacitybuilding efforts, create governance mechanisms in their guise. Meanwhile pressure to adopt or reject particular types of projects is forthcoming from transnational business and from NGO campaigns that have financial and political stakes in the fate of CDM projects. To differing degrees, these actors shape the context with which states makes decisions and the contours of policy space and policy autonomy (Gallagher, 2005) that states have available to them. It is at the interface between these international pressures and domestic politics that patterns of convergence and divergence work themselves out depending on the power of the state and international actor in question. In this sense, the degrees of divergence across the countries explored in this special issue, despite a certain commonality of actors, procedures, and modes of governing noted in the introduction, should not be surprising.

The pressures states face are "domesticated" in very diverse ways (Newell, 2008b) with important implications for decision making at the demand and supply side of carbon governance. As each of the articles show, there are both tendencies toward convergence and divergence in carbon governance associated with the CDM. Pressures toward convergence come from uniformity in methodologies, globally agreed rules, and from the "market makers" (project developers and verification agents) that operate simultaneously in many markets adopting similar practices and in so doing 
establishing benchmarks and norms of conduct. But the articles demonstrate a variety of carbon governance in operation, an array of political processes at work in terms of who governs, and how, and ultimately, who benefits from CDM projects. In this short contribution, I identify a number of key cross-cutting themes in relation to varieties of carbon governance that emerge in different ways in each of the articles, which are central to the question of the effectiveness of the CDM.

Each theme relates to the question of power: power to define what is and is not clean and sustainable development, the power that determines which countries are able to steer CDM investments toward sectors aligned with their overall development priorities, and the combinations of public and private power that demonstrate as well as explain the varieties of carbon governance documented in this special issue. My argument is that the observed diversity of carbon governance reflects differences in governance in general in those countries. Given the intimate nature of the relationship between energy, production, and power, because of the centrality of energy to growth upon which state legitimacy often rests, it is impossible politically, and unhelpful conceptually, to attempt to understand carbon and clean development governance without reference to the broader political-economic context in which it is embedded and which it seeks to transform. But whether it is in the area of energy, waste, or forests, CDM governance is incorporated within and predated by political structures, institutions, conflicts, and interests that shape the amenability of a sector and country to pressures toward convergence, standardization, and universalization.

\section{Drawing Boundaries}

The first issue is the question of who draws the boundaries around what is to be governed, what is not, and by whom (Newell 2008a). This relates to the politics of who gets to define what is meant by clean development and sustainable development. A great deal of lobbying surrounds the inclusion or exclusion of particular sectors and methodologies within the CDM under the remit of its executive board. Flues, Michaelowa, and Michaelowa (2008) found, for example, that having a member on the board from the country where a project originates does increase its chances of being approved. The question of how sustainable development, one of the key contributions of CDM projects, is to be defined is deferred to national government authorities. We have seen how Brazil has spelled out clear criteria aimed at preserving the environmental integrity of projects, whereas other countries have adopted a more laissez-faire approach; in China's case by assuming that if projects are in areas identified as national priorities, they, by definition, contribute to sustainable development. Reflecting different views of carbon markets and distinct policy styles and ideologies of regulation, China had a policy of requiring that projects are at least $51 \%$ Chinese owned (though this is set to be relaxed) and levies a tax on those projects that are least aligned with its overall national priorities such as industrial gas projects that attract a $65 \%$ levy. The approach that Schroeder describes of steering CDM investments into areas not prioritized by international CDM rules is consistent with a proactive, developmental-state approach 
to environmental issues where China seeks to engage with the international community on its own preferred terms (Keeley, 2005; Newell 2008a). India, by contrast, as Benecke's article shows, has adopted a "market facilitation" role: neither imposing taxes nor proactively intervening in what the government considers to be a marketplace. 1 These policy styles go beyond differences in the resources and capacity of states in terms of their ability to monitor projects for additionality and sustainable development benefits. They reflect different political economies and ideologies regarding the appropriate relationship between the state and market. The issue is often also political will rather than capacity per se. Benecke argues, for example, that the designated national authority (DNA) in India has sufficient human, technical, and financial resources to engage in more stringent additionality testing or sustainability assessments, but chooses not to do so.

Unsurprisingly, there has also been considerable contestation not only around the technical (though also of course highly political) boundaries around which methodologies are approved and which criteria should be fulfilled, but around who is served by clean development governance. Generic critiques question the additionality of projects, which stems from their tendency to displace the problem of reducing GHG emissions onto southern countries that currently do not have reductions obligations under the Kyoto Protocol (Bachram, 2004; Lohmann, 2005). There have also been localized protests around the sites of particular projects, as Friberg shows in the case of the Plantar project supported by the World Bank in Brazil, or objections to the fact that CDM funds often provide landfill sites with a new line of credit and incentive to continue operating where previously there had been demands for their closure (International Rivers, 2009; Lohmann, 2006). Hence, though the articles here do not find much evidence of local opposition to CDM projects, the fact that project design documents (PDDs) do not document objections or that DNAs do not receive letters of objection should not alone be taken as evidence that projects are welcomed by those expected to host them. In many cases, there is a lack of consultation about proposed projects or, where objections are raised, they are not recorded or deemed significant. I came across an example where participants in an event about a proposed project said they did not feel they had been given enough information to be able to meaningfully make a decision one way or another about whether the project would be beneficial. Yet the PDD records that there was positive support for the project. My own field work suggests that DNAs often concede that lack of capacity and resources mean they are not in a position to verify the claims project developers and investors make about support for a project or the extent to which a consultation with affected stakeholders has even taken place.

The question of what, by implication, is not subject to governance, is also highly political. Activities covered by the CDM form one tiny part of overall flows in the energy sector, for example, from trade, aid, production, and finance, little of which is directly governed by public bodies charged with tackling climate change. Official development assistance (ODA) funds for climate change mitigation are currently less than $1 \%$ of investment globally (United Nations Framework Convention on Climate 
Change [UNFCCC], 2007). In other words, most investment in the development sectors that need to be clean is largely ungoverned in a traditional sense (Newell, Jenner, \& Baker, 2009). A recent report by the World Resources Institute (WRI) found that during the past 3 years, less than $30 \%$ of the World Bank's lending to the energy sector has integrated climate considerations into project decision making. As late as 2007, more than $50 \%$ of the World Bank's $\$ 1.8$ billion energy sector portfolio did not include climate change considerations at all (WRI, 2008). This has implications not only for the effectiveness of CDM governance, which will be dwarfed by these larger flows of public and private finance, but also forces us to reflect on how much governance of clean development (above and beyond the CDM) actually takes place. The challenge for CDM reform proposals, as well as initiatives such as the Asia-Pacific Partnership on Clean Development and Climate (APP) and the REEEP (Renewable Energy and Energy Efficiency Partnership) in which India and China are involved, is to influence this wider scenario, which is currently neither aligned with the imperatives of action on climate change nor the promotion of sustainable development.

The question of what is and what is not clean development governance is not just an issue for international institutions, however. CDM governance spills over into and at the same time is defined by other policy areas at all levels of decision making. In thinking about how the CDM changes the national context, it is also important to bear in mind the regimes of governance and resource control that predate the CDM and were already in place around energy, waste, and forests each with their own actor networks, conflicts of interests, and programs of regulation. To take an example from my own field work, the methane-flaring projects on landfill sites in Argentina are caught up in the local politics of waste management that touches on an informal scavenger economy, a city mayor in Buenos Aires with interests in waste collection and discontented residents seeking to shut down a waste site that is now home to a CDM project. CDM projects and the funding that comes with them are received into and understood in relation to preexisting political priorities, relations, and institutions that, if they are to be effective, they have to engage and transform. We see in Schroeder's article how the CDM is seen in China, as elsewhere, as an add-on, something that adds value to ongoing projects and activities, but not something that is likely to bring about wholesale change. Friberg also shows that the extent to which and the ways in which forest projects are included in the CDM will have huge implications for local conflicts over land and property rights in the Brazilian Amazon that are likely to shape the course of CDM development in the country.

These examples suggest that forms of (carbon) governance vary not just by region and country, as the articles in this special issue amply show, but also by the resource subject to governance or the gas that is to be reduced. I am referring here to the materiality of governance. It matters whether it is carbon or methane or hydrofluorocarbon (HFC) that is being governed because they imply different circuits of production and consumption, uneven social and environmental consequences, and, therefore, different political stakes. It is not just the question of demonstrating additionality in the absence of existing regulation or alternative revenue flows, which is easier with some gases and projects of a certain scale than others. Nor is it just the question of the 
"governability" of the gas and its properties: How easily it can be subject to monitoring, capture, and reduction or destruction whether the finance flows at all will depend on the value attached to the broader resource economy or production network of which the potential project is a part: the ability to capture value while externalizing some of the costs. Destroying HFCs is relatively straightforward and does not directly affect the interests of other resource providers in the same way as fuel switching might or the way setting up a hydro project may imply social dislocation for affected communities. Given the long history of the antidam movement in India, such projects are particularly sensitive, to say nothing of the economic interests at stake in trying to conserve Brazil's rainforests.

\section{The Multiplicity of Governance}

A second key theme is how we define and what we mean by governance. The introduction by Fuhr and Lederer drew a neat distinction whereby "The setting up of rules is an act of governance whereas the anonymous coordination of demand and supply that constitute market mechanisms is not" (p. 6). One thing that emerges from these articles as well as my own research, however, is that dense networks underpin CDM deal brokering that is often far from anonymous, but rather results from lobbying, exchange, and networking between the buyers and sellers of CERs and intermediary organisations. Several of the articles show that social capital in the form of trust on the part of buyers is crucial to the success of market operations and service providers such as project developers and DOEs. It is also possible to show that the agreements, norms, networks, and customs, above and beyond legal contracts or private voluntary initiatives such as the CDM Gold Standard, do constitute forms of governance in so far as they shape and constitute the "rules of the game" by which participants abide and provide incentives and disincentives to behave in particular ways. This suggests that governance functions cannot be reduced to rule making alone.

This is important in capturing the range of governance functions that are performed by armies of DOEs, accountants, brokers, and intermediaries: the market makers who are essential to the day-to-day functioning of carbon markets. Though not formally rule makers, as subjects and sources of political action in carbon markets these actors are governance agents - the "street level bureaucrats" of the carbon economy (Lipsky, 1983). Hence, these governance agents, though not authoritative actors in a traditional sense of being bestowed with legal and sanctioning powers, are engaged in broader forms of steering and social control. By performing day-to-day functions of accounting, monitoring, measuring, and auditing they enable the carbon economy to function, verifying and allocating value, facilitating exchange, and building trust in the credibility of transactions in the market. Definitions of governance are necessarily blurred when public and private actors move between roles of regulator and project developer, as they do, frequently, and with ease. Schroeder shows how DOEs in China are seen as too closely connected to government to be independent, and Benecke observes the fragility of the distinction between project developers and project consultancies in the case of India, where their relationship is often "symbiotic." 
This blurring of public and private authority also occurs in terms of the interrelationship between different forms of clean development or carbon governance. The articles show that there are many forms of governance that overlap and interact in distinct ways. The composition of public and private authority differs by context with the China case showing most evidence of state-led regulation. But there are examples of private regulation (the gold standard projects in China), hybrid, and public-private partnership (PPP) arrangements (such as REEEP and APP and World Bank and UNDP [United Nations Development Program] carbon finance initiatives in India and China). The REEEP partnership alone has more than a 100 projects in its portfolio and, in October 2008, issued a new project call of more than $€ 4.3$ million, particularly for projects in priority countries including Brazil, China, and India. This perhaps is where the variety is most striking: the intermingling of actors, public and private, across scales (from global to local) in the construction and delivery of carbon governance.

And yet there is a need to strike a note of caution about claims of novelty regarding carbon governance. The claim is made that it is the increasing interaction of state and nonstate actors that makes them new. But globally, there is already a long history of civil regulation, coregulation, as well as PPPs going back and even predating the Johannesburg World Summit on Sustainable Development in 2002 (Bäckstrand, 2008; Pattberg, 2007). In terms of the range of actors and forms of governance at work, how different is the CDM from projects funded and overseen by the Global Environment Facility or the World Bank, or other newer PPPs such as the APP or REEEP? In many ways the CDM can be considered as part of a broader trajectory of voluntary marketbased instruments consistent with a trend toward the "marketisation of environmental governance" (Newell, 2005) that the editors note in the introduction. Perhaps the novelty derives from the range of actors operating across scales that are required to make the CDM market function or from the nature of the circuits within which value is created. These actors are enrolled to translate global decisions about the construction of a market mechanism, and a set of rules about the way in which it should operate, into concrete projects on the ground whose delivery is then monitored and communicated to a global body who issues credits that then move throughout the global carbon economy.

\section{The Centrality of Power}

The introduction rightly notes that much governance literature is grounded in examples from OECD countries, a fact that serves to reproduce assumptions about how states, markets, and civil society work that fail to adequately describe the conditions that prevail in the majority world, including those countries that are the subject of the analysis in this special issue. Assumptions about state resources and capacity, about process and implementation are reflected in the text of the Marrakesh accords, especially about how institutions and market actors should interrelate in the governance of the CDM. Yet these articles show how informal carbon economies can subvert their intent, as Chinese students cut and paste the contents of PDD to earn consultancy 
payments or national DNAs and regional offices struggle to cope with the demand from project developers and buyers. CDM governance, however, carefully designed from above, is unable to overcome or compensate for governance deficits at the national and subnational level in terms of accountability, transparency, and legitimacy. Benecke's article shows how the Indian government has been forced to tighten its approval processes as home to the greatest number of rejected projects $(50 \%$ of the worldwide total) and amid serious concerns about the additionality of projects it hosts. Likewise, if Brazil engages in forestry CDM projects, it will encounter the problem Friberg identifies in this article How to police and enforce logging and land use laws in the Amazon region - an area roughly the size of the EU — that lacks much basic infrastructure such as roads and telecommunications." There is often a substantial gap between global ambitions for carbon governance and the reality in the contexts in which it is meant to operate.

Beyond issues of capacity and good governance, power is also crucial to the governance of CDM in another sense. There are issues of autonomy and the power that is revealed in negotiations and conflict between CDM rules, methodologies, and priorities on the one hand and national development objectives, strategic preferences, and ways of working on the other (Newell et al., 2009). Some states have more power to attract investors on their terms than others. They have greater degrees of autonomy or policy space available to them to set the terms of engagement by private investors and international institutions (Gallagher, 2005). Each of the countries analyzed here is a powerful economic actor in its own right and provides an attractive investment climate for those looking to invest in CDM projects, a fact that allows them to specify sustainable development criteria, as in the case of Brazil, or impose taxes and investment restrictions in the case of China, without fear of deterring investors. This is clearly not the case for many sub-Saharan African countries, for example, on a continent that hosts just $1.86 \%$ of registered CDM projects (UNFCCC, 2009). Interestingly, many of the articles in this issue show how the CDM has served to mirror, some might argue reinforce, inequities in flows of finance, not just between countries but also within countries. Despite proactive attempts by the Chinese government to steer investors toward the poorest parts of the country, in all the country cases featured here (China, India, and Brazil), the wealthier the region the more likely it is to attract CDM projects.

There is often a strong tendency in governance literatures to emphasize problems of coordination and efficient management at the expense of conflict. Yet power inevitably runs through all systems of governance, including carbon and clean development governance. Power is decisive in the resolution of the many conflicts or trade-offs between forms of carbon governance that aim, for example, to achieve the following: economic efficiency as opposed to ecological effectiveness, an inclusive process as opposed to one that is less bureaucratic and fast track, striking a balance between achieving high environmental gains (HFCs) and socially beneficial outcomes (renewables), or small-scale as opposed to large-scale projects that earn lots of CERs but perhaps deliver fewer benefits to host communities. A key question then is, how do institutions or policy processes manage these trade-offs and the power relations that underpin them and on whose behalf? Friberg describes a successful business 
campaign aimed at persuading the Brazilian government to reverse a decision that threatened the financial viability of renewable energy projects in large parts of the country, whereas Schroeder shows that business lobbying is notable by its absence in China because a different structure of political representation exists and a different relationship between the state and (private foreign) capital.

Many of the articles in this special issue highlight the elite nature of the world of CDM governance, whether it is the private deals struck between buyers and sellers of CERs; closed negotiations between governments and international institutions such as the World Bank, UNDP, or regional development banks such as the Asian Development Bank; or the lack of civil society and broader public engagement around projects and priorities. Despite the rhetoric of contributing to sustainable development, most people whose interests are invoked in justifying the use of CDM mechanisms do not participate in decision making, even over projects that directly affect their livelihoods. Yet questions of participation, representation, and accountability are crucial to the legitimacy of carbon governance. If we are serious about improving the contribution of CDM projects to sustainable development, mechanisms of answerability and redress for those communities expected to host projects, who are rarely consulted about them, or of governments and the CDM executive board to those whose projects they accept and reject is urgently required (Newell 2008c). Some governments have been more proactive and demanding regarding process considerations than others. Brazil has an established procedure for public consultation, whereas in China there is less democratic space to contest projects approved by the government.

\section{Conclusion}

By way of conclusion, it is worth reminding ourselves that there are a number of contingencies and unknown variables at work here regarding what sorts of targets, if any, will emerge from Copenhagen, which sectors will be included or not, whether there will be moves toward sectoral approaches, and even whether countries such as China will be able to participate in a future CDM. The extent of U.S. demand for CERs to meet possible reductions commitments is also yet to be determined. Each of these factors will change the incentive structure and strategies of the states that have been under discussion here. Policy preferences on the demand side of carbon governance in terms of how far Annex 1 parties are able to meet their commitments through the purchase of offsets (supplementarity) and whether these are restricted to CERs as opposed to AAUs (assigned amount units) from transition economies (which Japanese but not European firms are permitted to purchase for example), all affect the market for CDM projects. As noted above, beyond the formal climate regime and the role of international and national public regulation, a critical role remains for the private sector and international economic institutions. The CDM market may well survive the downturn produced by the current economic crisis and uncertainly about the nature of the post2012 market, but demand will need to be sustained by high levels of interest from the financial and business community that has played a key role in creating carbon 
markets and sustaining demand for the compliance and voluntary offsets traded within them. To some extent there is a chicken and egg situation here where the level of interest from private investors will be a function of the stringency of a target agreed at Copenhagen and the extent to which it sends a clear signal to market actors that investments in GHG reduction will have a long-term value. Yet the nature of the target will also reflect how much scope governments feel there is for business to reduce their emissions further in a time of economic crisis.

This suggests that public multilateral, regional, and bilateral institutions such as the World Bank and Asian Development Bank also have a key role to play in stimulating investment in general and, in particular, reducing the risks of investment in poorer regions of the world that have not so far benefited from CDM investment. Together with the UNDP through its Millennium Development Goal Carbon Facility and regional development banks, the World Bank can use its power and resources to encourage the alignment of the CDM with other developmental priorities. Because poverty alleviation is a key state objective for China, India, and Brazil, the success of the CDM will be determined by the extent to which it can enhance, support, and add value to existing state development strategies. This might include support to pro-poor interventions in the energy, transport, and agricultural sectors: making interventions viable that would not be supported by other means. At the same time, to be credible, these global institutions need to address their own contribution to unclean development.

Such interventions and policy shifts will not overcome the inevitable divergences in governance among countries in terms of their institutional capacity, political culture, and political economies, but they may help to induce forms of convergence around the pressing need to ensure that the CDM is not seen as separate from development as usual, or as a boutique market, but as a component of a broader transition toward clean development and clean energy in particular. In a world in which 1.6 billion people are currently without electricity, where electricity demand in developing countries is projected to increase 3 to 5 times over the next 30 years (Davidson et al., 2003), and where, without a significant change of course, most of this will be fossil-fuel-based electricity production, clean development is an imperative for all.

\section{Acknowledgment}

I am grateful to Markus Lederer and Raymond Clemençon for useful comments on an earlier draft of this article.

\section{Note}

1. This in spite of the existence of policies at state level that require a certain percentage $(70 \%$ in the case of Karnataka) of CERs income to remain with the utility owners and growing national efforts to attract funding for rural electrification programs.

\section{References}

Bachram, H. (2004). Climate fraud and carbon colonialism: The new trade in greenhouse gases. Capitalism, Nature, Socialism, 15(4), 10-12. 
Bäckstrand, K. (2008). Accountability of networked climate governance: The rise of transnational climate partnerships. Global Environmental Politics, 8, 74-102.

Davidson, O., Halsnæs, K., Huq, S., Kok, M., Mertz, B., Sokona, Y., et al. (2003). The development and climate nexus: The case of sub-Saharan Africa. Climate Policy, 3(1), 97-113.

Flues, F., Michaelowa, A., \& Michaelowa, K. (2008). UN approval of GHG emission reduction projects in developing countries: The political economy of the CDM Executive Board (CIS Working Paper No. 35). Zurich, Switzerland: CIS.

Gallagher, K. P. (Ed.). (2005). Putting development first: The importance of policy space in the WTO and international financial institutions. London: Zed Books.

International Rivers. (2009). Global warming. Retrieved May 5, 2009, from http://internationalrivers.org/en/global-warming

Keeley, J. (2005). Interrogating China's biotech revolution: The developmental state meets the risk society. In M. Leach, I. Scoones, \& B. Wynne (Eds.), Science and citizens: Globalization and the challenge of engagement (pp. 155-166). London: Zed Books.

Lipsky, M. (1983). Street-level bureaucracy: Dilemmas of the individual in public services. New York: Russell Sage.

Lohmann, L. (2005). Marketing and making carbon dumps: Commodification, calculation and counter-factuals in climate change mitigation. Science as Culture, 14, 203-235.

Lohmann, L. (2006). Carbon trading: A critical conversation on climate change, privatisation and power (Development Dialogue No. 48). Dorset, UK: The Corner House.

Newell, P. (2005). Towards a political economy of global environmental governance. In P. Dauvergne (Ed.), Handbook of international environmental politics (pp.187-202). Cheltenham, Gloucestershire, UK: Edward Elgar.

Newell, P. (2008a). The political economy of global environmental governance. Review of International Studies, 34, 507-529.

Newell, P. (2008b). Lost in translation? Domesticating global policy on GMOs: Comparing India and China. Global Society, 22, 115-136.

Newell, P. (2008c). Civil society, corporate accountability and the politics of climate change. Global Environmental Politics, 8, 124-155.

Newell, P., Jenner, N., \& Baker, L. (2009). Governing clean development: A framework for analysis (The Governance of Clean Development Working Paper Series No. 1). Norwich, Norfolk, UK: University of East Anglia.

Pattberg, P. (2007). Private institutions and global governance: The new politics of environmental sustainability. Cheltenham, Gloucestershire, UK: Edward Elgar.

UNFCCC. (2007). Investment and financial flows to address climate change. Bonn, Germany: Author.

UNFCCC. (2009). Registered projects by region. Bonn, Germany: Author. Available from http://cdm.unfccc.int/Statistics/Registration/RegisteredProjByRegionPieChart.html

WRI. (2008). Correcting the world's greatest market failure: Climate change and multilateral development banks. Available from http://www.wri.org/publication/correcting-the-worldsgreatest-market-failure

\section{Bio}

Peter Newell is professor of international development in the School of International Development at the University of East Anglia and an ESRC climate change leadership fellow for a project on The Governance of Clean Development (http://www.clean-development.com). 